\title{
ANALYSIS OF THE METHODS FOR REGISTRATION OF IMAGES RECEIVED FROM THE INFORMATION SYSTEMS OF NON-MOTORIZED AIRCRAFTS
}

\author{
Venelin Terziev ${ }^{1}$ and Teodora Petrova ${ }^{2}$ \\ ${ }^{1}$ Full Member of the Russian Academy of Natural History, Professor, Eng., D.Sc. (National \\ Security), D.Sc. (Economics), D.Sc. (Social Activities), Ph.D., Russian Academy of Natural History, \\ Moscow, Russia, Vasil Levski National Military University, Veliko Tarnovo, Bulgaria University of \\ Rousse, Rousse, Bulgaria, terziev@skmat.com \\ ${ }^{2}$ Assoc. Prof. Ph.D., Faculty of Aviation, Vasil Levski National Military University, Dolna Mitropoliya, \\ District Pleven, Bulgaria, teodorapetrova33@abv.bg
}

\begin{abstract}
The non-motorized air systems for intelligence, monitoring and control of the earth surface have gained currency and are used for various tactic flight's tasks and missions. The non-motorized aircrafts (NMA) and the air-monitoring systems that include board and land part are key elements of these systems. The world experience in using NMA for these uses shows that they are most suitable where the exploitation conditions are very extreme and there is an unacceptable risk for operations of piloted aviation. Such are intelligence and observation of strictly guarded sites, zones, where military operations are conducted as well as regions with large scale fires and floods. The use of people in these conditions is connected with actual threat for their lives and practically, NMA as a tool for collecting and processing of information is irreplaceable.
\end{abstract}

Keywords: registration of images, methods, information systems, non-motorized aircrafts.

\section{INTRODUCTION}

The non-motorized aircrafts find wider and wider application in the recent years for solving wide range of tasks in military science, ecology, environment monitoring, calamities and averages. Non-motorized aircraft systems for intelligence, monitoring and control of the earth surface have gained wide distribution and are used in various tactic flight's tasks and missions. Key elements of these systems are the non-motorized aircrafts (NMA) and the systems for air monitoring that include board and land part. The world experience in using NMA for these uses shows that they are most suitable where the exploitation conditions are very extreme and there is an unacceptable risk for operations of piloted aviation. Such are intelligence and observation of strictly guarded sites, zones, where military operations are conducted as well as regions with large scale fires and floods. The use of people in these conditions is connected to actual threat for their lives and practically, NMA as a tool for collecting and processing of information is irreplaceable.

\section{ANALYSIS OF THE METHODS FOR REGISTRATION OF THE IMAGES RECEIVED FROM THE INFORMATION SYSTEMS OF NON-MOTORIZED AIRCRAFTS}

Monitoring the air space, the earth and water surface, depending on the particular tasks that are to be solved, air-pictures, hydro-meteorological situation, atmosphere study, radio-metric control of calamity areas, 
seismic control, control of the status of gas and oil pipelines, the electricity supply network, geological studies, under-surface earth sounding, study of the ice situation, see motion could be made.

The scope of civil NMA application is:

- Small objects finding - air, over water, land;

- Air transport management - in hardly accessible areas, at vehement calamities and averages, of temporary airways in civil aviation;

- Control of sea vessels movement - searching for and finding vessels, warning for average situations in the ports, control of sea borders, control of proper fishing;

- Development of regional and cross-regional telecommunication networks - the connecting systems including the mobile ones, tele-radio-broadcasting, the navigation systems;

- Taking air pictures and control of the earth surface - cartography, inspection and observation of contractual obligations, control of the hydrologic and meteorological situation;

- Environmental situation control - radiation control, gas and chemical control, control of gas and oil pipelines, test of seismic sensors;

- Ensuring agricultural work and geologic studies - defining soil characteristics, study for minerals, under surface (up to $100 \mathrm{~m}$ ) earth sounding;

- Ocean studies - study of the ice, study of the sea motion, searching for fish shoals.

A range of useful load is developed for NMA that includes digital camera, different types of tele-cameras and sensors, system for laser mapping (LIDAR), radar for synthesized aperture, which allows satisfaction of wide scope of clients' requirements.

The data from the useful NMA load could be transferred in real time to a remote terminal placed in an automobile, plane or helicopter that execute target tasks (search for victims, for extinguishing fire, etc.). The remote terminal could be based, in particular, on the grounds of a portable computer and to include also receiving device with antenna.

Solving such type of problems, various types of sensors and systems are used, in particular, monitoring visualizing systems working in the optic spectrum range $-0,2-12$. Despite their variety, each type of monitoring system in the optic range has limitations and specific possibilities when loaded on NMA.

Using radar with synthesized aperture gives great possibilities because it is designed for work in any weather conditions. In normal mode of functioning, it ensures receiving radio-location images of a terrain with resolution 1 meter. For a twenty-four hours, an image of an area of $138000 \mathrm{~km} 2$ at a distance of $200 \mathrm{~km} 2$ could be received. In points mode, a picture with size of the terrain of $2 \times 2 \mathrm{~km}$ is received, and for 24 hours, more than 1900 images could be received with resolution of $0,3 \mathrm{~m}$. In the third mode, the radar could accompany moving targets if its speed is over $7 \mathrm{~km} / \mathrm{h}$.

A day digital-optic camera that ensures receiving images with high resolution. Sensor $(1024 \times 1,024$ pixels), connected to a telephoto lens with focal length $1750 \mathrm{~mm}$. Depending on the programme, there are two modes of functioning. The first is scanning in a strip $10 \mathrm{~km}$ wide. And the second one is detailed image of a terrain of $2 \times 2 \mathrm{~km}$. An infrared (IR) sensor ( $640 \times 480$ pixels) that uses the same telephoto lens is used for receiving night images.

Number of channels for connection could be used for transferring the information to the users. Along the satellite channel, the speed of transferring information is $50 \mathrm{Mbit} / \mathrm{sec}$. Information with speed $137 \mathrm{Mbit} / \mathrm{sec}$. could be transmitted along a channel of UHF range.

The interest toward NMA is provoked by their inexpensive exploitation and avoiding the risk for the crew. The limitation of the exploitation load is defined by the physiologic abilities of the person, the possibility for maintaining monitoring at multiple points for a very short period of time.

NMA could bring benefit and economies not only for the military but in the civil field. Their possibilities depend on a parameter such as height of flight up to $30 \mathrm{~km}$. At such a height, the non-motorized aircraft could compete with the satellites that are at a height of about 400 kilometers. They could track everything that happens on a territory with area of about a million of square kilometers, which turns them into kind of „aerodynamic satellite". The non-motorized aircrafts could take the functions of satellite groupings and to execute them in real time mode within the limits of a whole region.

24 satellites are necessary to make photo- and movie pictures from space or to monitor any objects, but 
even then the information from them would be submitted once in an hour. The point is that the satellite is over the monitored object for only 15-20 minutes and then gets out of its visibility zone and gets back to this very same spot after making a revolution in a circle around the Earth. In contracts to the satellite, the nonmotorized aircraft follows the point of monitoring constantly. It works at a height of $20 \mathrm{~km}$ more than 24 hours but returns to the base and another one takes its shift in the sky. One more appliance stays in reserve. This is great economy because the non-motorized aircrafts are considerably cheaper than the satellites.

The non-motorized aircrafts could compete with the satellites in the field of establishing telecommunication networks and in the navigation systems.

The non-motorized aircrafts could be assigned continuous circular twenty-four hours monitoring of the earth surface in a wide range. Using them, we could create an information field of the country that includes control and management of the air and water transport, because these appliances could have functions of land, air and satellite locators (the current information from them gives a full picture of what happens in the sky, in the water and on lands).

The NMA advantages are in the fact that first, they are considerably cheaper than the piloted aircrafts. Also, pilots have to be trained and this costs a lot of money. As a result of the absence of a crew onboard, the expenses for executing a task reduce considerably. Second, the light-weighted (in comparison to the piloted aircrafts) non-motorized aircrafts consume less fuel. A more realistic perspective opens before them even at a possible transition to cryogenic fuel. Third, in contrast to the piloted aircrafts, the NMA do not need airports of special surface.

NMA have gained wide popularity thanks to their possibility to receive various radio-technical information from terrain, where placing an operator (observer) is difficult. The progress of computing equipment and the digital technologies for signals processing (Bezryadin, 2003; Gruzman et al. 2000; Prett; 1982) allows considerable improvement of the quality, speed and volume of images procession and ensuring their transmission over big distances. Alongside, digital technologies have their disadvantages that influence their effectiveness when used in monitoring tools.

The technical monitoring systems are realized as optic appliances systems, placed immediately in the NMA body and solidly attached to its construction or with the help of gyro-stabilized platforms that ensure turning of the systems' optic axes to all sides with preset speed. As a rule, the appliance's optic axis solid connection with the NMA construction is used with the viewing aviation cameras and optic appliances in the front or other hemispheres of the aircraft.

The optic sensors and cameras differ considerably in dimensions and bulk and the realization of such specific requirements as distance to the object for photographing and the high terrain's resolution lead inevitably to these systems bulk and value increase.

Practically, all optic appliances mounted in the aircraft's construction have the possibility for a certain angular shifting for compensation of the aircraft's angular position towards Earth's surface and of the aircraft's angular fluctuation regarding the normal coordinate system's axes (Petrov, 2010).

The use of such appliances allows solving great amount of practical tasks but in order to get a quality result, the fulfillment of strict enough requirements towards the aircraft's stabilization in the air at the moment of monitoring is necessary. Unfortunately, such systems' functioning principle as a whole does not allow realizing modes of accompanying of targets, and when trying to realize such a mode, great amount of difficulties and limitations occur.

The optic appliances placed on gyro-stabilized platforms appear to be more flexible. The world practice has accumulated considerable experience in using such appliances and the market of electronic-optic monitoring and intelligence systems offers sufficiently wide range of such appliances (Petrov, 2010a; Petrova, 2019; Petrov, 2015; Petrov, Miron, 2019a).

The using of gyro-stabilized platforms in the optic monitoring systems ensures the solution of the problem with accompanying a selected target at NMA evolutions in flight or change of the target's spatial position. The joint mounting of television and infrared camera allows considerable improvement of the received image's information, and using additional laser range-finder - target indicator gives possibility for the targets coordinates precise defining.

Considering the great variety of the offered optic systems for NMA, the question with selection of equipment depending on the tasks to be executed arises, and to estimate the effectiveness of using the selected appliances.

The following main tasks were reviewed in the process of study: 
To estimate the possibilities of the systems for ecologic monitoring, used in NMA

Necessity, actuality and main directions for development of the board systems for ecologic monitoring with using NMA. Finding, localization and announcing of arisen forest and fires and floods, taking into consideration the significance, place and tasks it is going to fulfill for improving the prevention and protection of country's population at these natural calamities, averages and crises arousal.

To ground the composition, block scheme, interconnections and criteria of evaluation in the ecologic monitoring systems on the base of modern requirements and regulating documents.

The analysis of the used modern appliances and systems for air and ecologic monitoring shows the digital methods for procession of images received from the board system has gained wide application.

Registering the images in the non-motorized aircrafts

Registering cameras are used for registering the images. In them, the various points of the objects' space are represented by the camera's optic system in the images' space at different distance from the focal plain. However, if the distance between the camera and the monitored scene exceeds the optic system's focal distance significantly, then it can be considered the image is built in its focal plain. In this case, projective model of camera can be used, where the image of the three-dimension object is received through projecting in the focal plane through one single point, which is called optic centre. The straight line, which is perpendicular to the plane of the image and crosses this point, is called camera's optic axis, and the optic axis' cross point with the image's plane - main point.

The gyro-stabilized platform's optic systems have acquired an important place in the NMA target loading. Their complexity and meaningful functional variety (accompanying a pint in space, calculating relative coordinates of a pint in space, etc.) constantly increase as well as the value of these appliances. That's why the task for evaluating the effectiveness of applying optic systems on gyro-stabilized platforms turns to be up to date. And the complexity of tasks that non-motorized equipment could be assigned is constantly increasing. The constructively optic systems on gyro-stabilized platforms are performed in a manner, where the lens (and the system of sensors) ensure relative turning in two axes connected in coordinate system OX and OY with angular speeds of $x$ and $y$. The utmost value of lens's angular turning is usually selected based on the NMA purpose, where the optic system would be mounted, but generally a circular view and scanning from an angle of place of about 1100-1200 is ensured. The positive value of the alfa angle ensures view and accompanying of an object that are higher that the aircraft's axis.

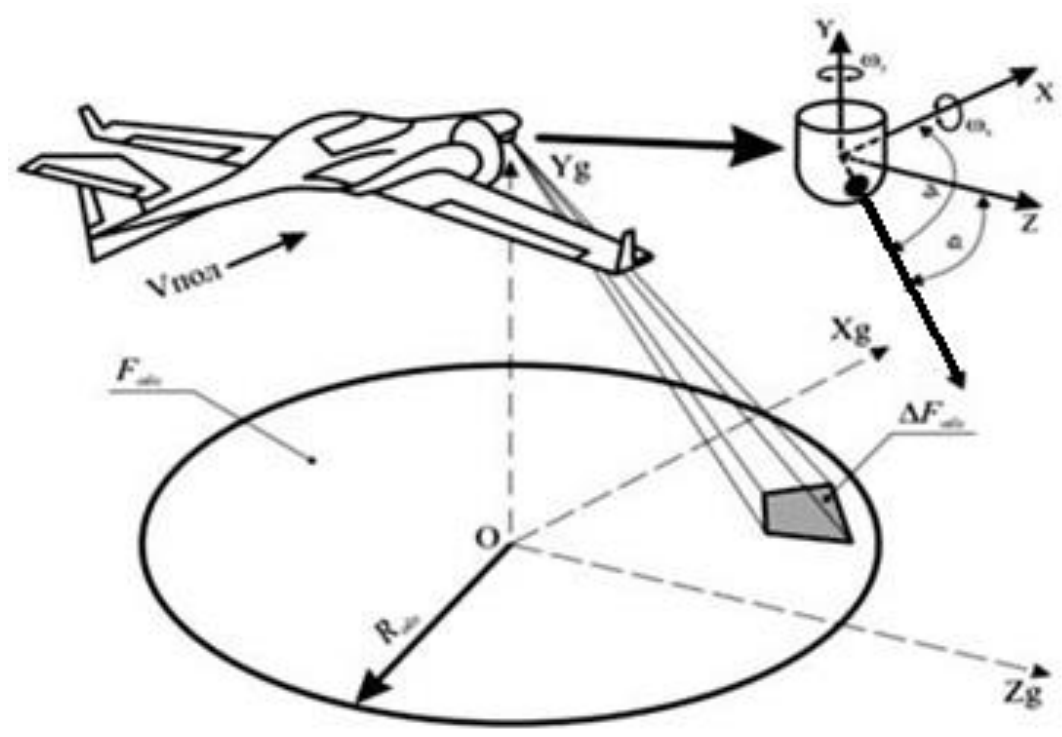

Figure1. Deciphering scheme for defining the effectiveness of the used optic system of a gyro-platform.

Such wide range of the lens's diversion angle ensures sustainable accompanying of the object at aircraft's manoeuvres and evolution with optic system.

The theoretic effectiveness at applying optic system that ensures circular view is defined conditionally by the probability the searched object to be in the reviewed area $F_{\text {reviewed }}$ (fig.1). Defining that indicator, the following conditions have to be taken into consideration: 
- The aircraft to have speed of flight $\mathrm{V}_{\text {flight }}>0$,

- The angular speed at lens's optic axis' turning $\Omega=\sqrt{\omega_{x}^{2}+\omega_{y}^{2}}$ to have limitation. With imitation modeled system "optic appliance - operator" it appears that the angular speed of optic axis' turning could not be bigger than $(0,06 \ldots 0,07) / \mathrm{L}$ ( $\mathrm{L}$-the inclined distance to the centre of the reviewed area in meters).

- The angular speed of lens's turning depends on the flight's speed, because of which the $V_{\text {flight }}$ and the value of the aircraft's angular speed of turning towards the normal coordinate system at perfect evolution should be taken into consideration. Otherwise, blurred image would be seen on the screen, where nothing could be possible to define.

- According to theoretic calculations, the foreseeable area has the shape of a circle and it is supposed that the earth surface is smooth and close to the surface of a sphere with radius equal to the Earth's radius. In reality, earth's surface differs considerably from the ideal one by all indicators received for ideal surface.

- The searched object is usually situated where nobody is looking for it. The conditional probability of finding an object with given parameters could be defined by the expression:

$$
P_{\text {обн }}=P_{н о} \cdot P_{\text {во }} \cdot P_{\text {поо }} \text {, }
$$

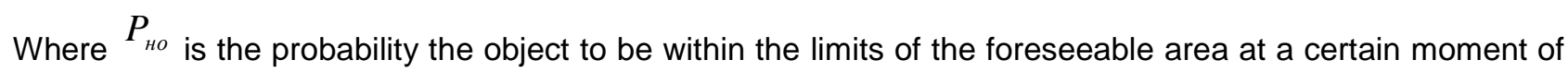
time. This tactic parameter does not depend on the optic system's features and characteristics. Because of that it is accepted it is equal to 1,$0 ; P_{n o o}$ - the probability the searched object to be in the area $F_{\text {ou }}$. It is not seen for this parameter to be dependable on the strategy for searching (i.e. on the law of lens's optic axis space position change in time) for aircrafts $(A)$ having $V_{\text {flight }}>0$. This dependence, as it would be later seen, has no any sense. That's why the value of $P_{\text {noo }}$ could be defined by the following expression:

$$
P_{\text {поо }}=K_{\text {зон }} \cdot \frac{\Delta F_{\text {обз }}}{F_{\text {обз }}} \text {. }
$$

In this case, $V_{\text {flight }}>0$ should be considered when the foreseeable area in the time has shape different from circle. Then:

$$
P_{\text {поо }}=\frac{\Delta F_{\text {обз }}}{\pi R_{\text {обз }}^{2}+2 V_{\text {пол }} R_{\text {обз }}} .
$$

$P_{B O}$ is the probability for instantaneous object's separation on the background of the spreading surface. It depends on the volume of the information coming for the searched object. If the volume of information is sufficient for accepting the hypothesis that this is the object we search for, then $P_{B O}=1,0$.

For simplicity and clearness, the following condition is accepted: if the object's projection occupies 1 pixel and more of the operator's screen, then $P_{B O}=1,0$.

The limited angular speed of lens's optic axis turning considerably limits the potential possibilities that are preset in the gyro-stabilized platform's optic-electronic device. The analysis shows that at flight speed of 30 $\mathrm{km} / \mathrm{h}$, such device becomes useless: it cannot realize its possibilities and the probability to get on the searched object in the area hardly reaches value of 0,05 . The view radius's increase sharply limits the probability of getting on the searched object in the area. In this regard, the optic system as main appliance which is solidly attached to the aircraft's construction (aviation cameras, TV cameras looking downwards, etc.) has significant advantage: with them $P_{\text {noo }}$ reaches values of $0,95-0,98$ of range. Number of conclusions can be made on the grounds of the data: 
- Choosing optic system for NMA, what we expect as final result of the non-motorized aviation system should be very carefully considered,

- The availability of the most perfect from technical point of view optic system on the board of NMA does not yet guarantee successful applying in practice,

- The bigger the size of searching area of the earth surface is, the more difficult the use of small NMA and micro NMA is for solving practical problems: in this case their effectiveness would not bare any critics.

Necessity, actuality and main directions for developing board systems for ecologic monitoring using NMA. Finding, localization and announcing of arisen forest and fires and floods, taking into consideration the significance, place and tasks it is going to fulfill for improving the prevention and protection of country's population at these natural calamities, averages and crises arousal.

The digital procession of images appears to be that part of signals digital procession (SDP), where the signal serves as image. The word "image" means "reproduction or representation of the shape of a human or object". The physical mechanism that creates the mentioned "reproduction or representation" has an essential significance. In daily life, getting an image is associated with the eyesight, i.e. with stimulating eyes' retina, and in this case, the image forming subdues to the laws of optics. However, technology has found many other ways for getting an image without the participation of retina. Recently, images are gotten often with the help of system of sensors that register such types of energy, to which the organ of eye sight does not react (here, synthesized radio-locators are included for example, the acoustic holography and the systems using penetrating radiation). Fortunately, having the whole variety of cases, where images are created and registered, they could be described with the help of the general mathematical apparatus.

Presence of distortion in the received images is one of the characteristics of the used optic systems. They could find expression in contrast reduction, geometric distortions, blurring, diluted image as result of camera's movement, etc. These impose the study of various algorithms for the received images restoration and improvement (Fisenko, Fisenko, 2008; Antonov, 2017; Antonov, 2018).

The images from radars with synthesized aperture have characteristically specific distortions different from those of the optic ones. The fight with them is held most effectively at the very creation of the image, not through procession of already received image as far as the trajectory and the parameters of NMA movement is necessary to be considered.

The described mathematical models of the optic and radar images creating systems allow for elaborating, analyzing and studying of different algorithms for distorted images' restoration as well as for their quality improvement.

Review and analysis of different types of algorithms for distorted images' restoration is necessary to be made on the basis of the forming systems' models. The algorithms should be optimized for various types of distortions - blurring, camera moving, geometric distortions, etc (Enimanev, 2001; Novakova, Enimanev, Andonov, 2007; Enimanev, 2007a-b; Enimanev, 2016; Enimanev, 2019b).

\section{CONCLUSION}

The various theoretically grounded and studied practically applied methods for procession of air-photo and radiolocation images offer algorithms for consecutive use of various methods aiming ensuring better possibilities for analysis of the information from the images. The great quantity of results of the application of various methods illustrates the peculiarities at applying the various algorithms and the effectiveness with their usage. Studies show that analyzing the objects in the images, the consecutive using of several algorithms for processing is necessary until reaching the desired result. Part of the results included in the monograph is published in the authors' articles, and greater part is received in the process of working on the monograph itself. The received results show that the various algorithms and methods' effectiveness is not the same, which requires the operators, who analyze the visual information to be well acquainted to their possibilities and peculiarities. 


\section{REFERENCE LIST}

Bezryadin S.N. (2003). Osnovnoy nedostatok sensorov sovremennayh tsifrovayh kamer, 2003 (Безрядин С.Н. 2003. Основной недостаток сенсоров современных цифровых камер, 2003).

Gruzman I.S., Kirichuk V.S., Kosayh V.P., Peretyagin G.I., Spektor A.A. (2000). Tsifrovaya obrabotka izobrazheniy v informatsionnayh sistemah: Uchebnoe posobie.- Novosibirsk: Izd-vo NGTU, 2000. 168 (Грузман И.С., Киричук В.С., Косых В.П., Перетягин Г.И., Спектор А.А. 2000. Цифровая обработка изображений в информационных системах: Учебное пособие.- Новосибирск: Изд-во НГТУ, 2000. - 168).

Prett U. (1982). Tsifrovaya obrabotka izobrazheniy. Kn.1. - М.: Mir, 1982 (Прэтт У. 1982. Цифровая обработка изображений. Кн.1. - М.: Мир, 1982).

Petrov, Zhivo. (2010). Algoritam za savmestna obrabotka na signali ot GPS I INS s izpolzvane na kalmanov filtar, Nauchni trudove na rusenskiya universitet - 2010, tom 49, seriya 3.2 str.18-22, ISSN 1311-3321 (Петров, Живо. 2010. Алгоритъм за съвместна обработка на сигнали от GPS И INS с използване на калманов филтър, Научни трудове на русенския университет - 2010, том 49, серия 3.2 стр.1822, ISSN 1311-3321).

Petrov, Zhivo. (2010a). Algoritam za savmestna obrabotka na signali ot GPS I INS s izpolzvane na filtar Monte Karlo, Nauchni trudove na rusenskiya universitet - 2010, tom 49, seriya 3.2, str.23-27, ISSN 1311-3321 (Петров, Живо. Алгоритъм за съвместна обработка на сигнали от GPS И INS c използване на фрилтър Монте Карло, Научни трудове на русенския университет - 2010, том 49, серия 3.2, стр.23-27, ISSN 1311-3321).

Petrova, Teodora. (2019). Izsledvane i sintez na algoritmi za obrabotka na radiolokatsionni i optichni izobrazheniya s povisheno kachestvo, Dolna Mitropoliya, 2019, ISBN 978-954-713-117-0 (Петрова, Теодора. Изследване и синтез на алгоритми за обработка на радиолокационни и оптични изображения с повишено качество, Долна Митрополия, 2019, ISBN 978-954-713-117-0).

Petrov, Zhivo. (2015). Izsledvane na mikroelektromehanichni inertsialni senzori, Pleven 2015 g, ISBN 978954-713-107-1 (Петров, Живо. 2015. Изследване на микроелектромеханични инерциални сензори, Плевен 2015 г, ISBN 978-954-713-107-1).

Petrov, Zh., Miron, L. (2019a). Opportunities Of a Genetic Algorithm For Static Calibration Of MEMS Accelerometers, International Scientific Conference Aviation Faculty, National Military University, 2019, p. 246, ISBN 978-954-713-123-1.

Fisenko V. T., Fisenko T. Yu. (2008). Kompyyuternaya obrabotka i razpoznavanie izobrazheniy, SankPeterburg, ITMO, 2008 (Фисенко В. Т., Фисенко Т. Ю. 2008. Компьютерная обработка и разпознавание изображений, Санк-Петербург, ИТМО, 2008).

Antonov S. I. (2017). Comparative analysis of the armament and equipment support modules in the field of command and control information systems of NATO armies, International Scientific Journal "Security \& Future“, Year I, Issue 4, p.p. 163-167, 2017, WEB ISSN 2535-082X; PRINT ISSN 2535-0668.

Antonov S. I. (2018). Researching the capabilities of information technologies for education in design, 3D modeling and visualization of the working principles of specific armament elements, International Scientific Journal „Mathematical modeling 2018“, Year 2, Issue 4, 2018, p.p. 156-159, ISSN (PRINT) 2535-0986, ISSN (WEB) 2603-2929.

Novakova, A., Enimanev, K., Andonov, K. (2007). Izsledvane na netnite ikonomii na energiya ot atmosferniya vazduh pri sahranenie na produktsiya. // Nauchno spisanie za selskostopanska i gorska tehnika, Ekologiya i badeshte, Sofiya, 6, 2007, 3, s. 3-13, ISSN 1312-0751 (Новакова, А., Ениманев, К., Андонов, К. Изследване на нетните икономии на енергия от атмосферния въздух при съхранение на продукция. // Научно списание за селскостопанска и горска техника, Екология и бъдеще, София, 6, 2007, 3, с. 3-13, ISSN 1312-0751).

Enimanev, Krasimir. (2007a). Algoritam i programa za optimalno orazmeryavane izolatsiyata na energoikonomichni stopanski sgradi. // Selskostopanska tehnika, Sofiya, XLIV, 3/ 2007, s. 29-36, ISSN 0037-1718 (Ениманев, Красимир. Алгоритъм и програма за оптимално оразмеряване изолацията на енергоикономични стопански сгради. // Селскостопанска техника, София, XLIV, 3/ 2007, c. 29-36, ISSN 0037-1718).

Enimanev, Krasimir. (2007b). Mehanizatsiya i avtomatizatsiya v zhivotnovadstvoto. // Selskostopanska tehnika, Sofiya, XLIV, 3/ 2007, s. 29-36, ISSN 0037-1718 (Ениманев, Красимир. Механизация и 
автоматизация в животновъдството. // Селскостопанска техника, Софияя, XLIV, 3/ 2007, с. 29-36, ISSN 0037-1718).

Enimanev, Krasimir. (2016). Kompleksna prostranstvena zavisimost na infrastrukturnite elementi pri planirano izgrazhdane na teritorialnite sistemi. // Mezhdunarodna nauchna konferentsiya, Ikonomichesko blagosastoyanie chrez spodelyane na znaniya, 09-10 noemvri 2016, Svishtov, 1, 2016, s. 331-335, ISBN 978-954-23-1185-0 (Ениманев, Красимир. Комплексна пространствена зависимост на инфраструктурните елементи при планирано изграждане на териториалните системи. // Международна научна конференция, Икономическо благосъстояние чрез споделяне на знания, 09-10 ноември 2016, Свищов, 1, 2016, с. 331-335, ISBN 978-954-23-1185-0).

Enimanev, Krasimir. (2019b). Energoefektivno osiguryavane na mikroklimata v zatvoreni agrarni sgradi chrez unifitsirani modulni elementi. Fakultet „Aviatsionen“, Natsionalen Voenen Universitet „Vasil Levski“, Dolna Mitropoliya, 2019, 224 str., ISBN 978-954-713-130-9 (Ениманев, Красимир. Енергоефективно осигуряване на микроклимата в затворени аграрни сгради чрез унифицирани модулни елементи. Факултет „Авиационен“, Национален Военен Университет „Васил Левски“, Долна Митрополия, 2019, 224 стр., ISBN 978-954-713-130-9). 